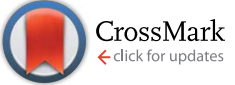

Cite this: RSC Adv., 2017, 7, 3145
Received 20th October 2016 Accepted 30th November 2016

DOI: 10.1039/c6ra25520e

www.rsc.org/advances

\title{
Synthesis and fungicidal activity of 3,4- dichloroisothiazole based strobilurins as potent fungicide candidates $\uparrow$
}

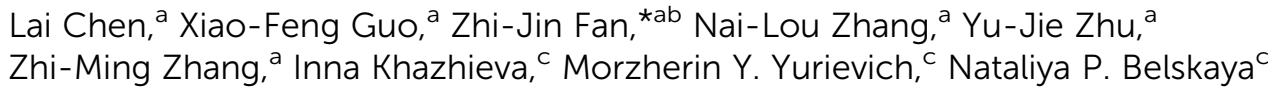

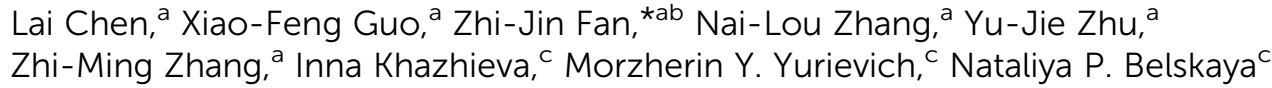 \\ and Vasiliy A. Bakulev ${ }^{\star c}$
}

A series of 3,4-dichloroisothiazole based novel strobilurin analogs were designed and synthesized, and their structures were elucidated by NMR and HRMS, and the typical crystal structure was determined by X-ray diffraction for validation. Results from different biological assays suggested that most target compounds displayed very good fungicidal activity against one or multiple plant pathogens in vitro and in vivo. Among them, compounds $6 \mathrm{~d}, 6 \mathrm{~g}$ and $8 \mathrm{~d}$ showed a broad spectrum of fungicidal activity. Further field experiments indicated that compound $\mathbf{8 d}$ displayed better efficacy against Sphaerotheca fuliginea than commercial standards azoxystrobin and trifloxystrobin, and better efficacy against Pseudoperonospora cubensis than trifloxystrobin. Overall, a new fungicidal candidate for plant disease management was discovered in this study.
\end{abstract}

\section{Introduction}

A sustainable food supply for an increasing global demand requires new innovations in crop protection technology. ${ }^{1}$ Continuous global population growth and a shift in consumers' food preference call for an increased crop yield under fixed/ shrinking arable lands. ${ }^{2}$ Agrochemicals have been one of the most effective tools to meet this need. However, pest resistance, pest shifts and an ever evolving regulatory landscape mean a high pressure for current agrochemicals. Innovative agrochemicals that can overcome resistance are always welcome for farmers. ${ }^{3}$

Resistance of plant pathogens to some strobilurin analogs needs innovative products. The strobilurin fungicides are the second largest group of launched fungicides, which act through inhibition of mitochondrial respiration by blocking electron transfer within the respiratory chain, thus in turn causes important cellular biochemical processes to be severely disrupted, and results in cessation of fungal growth. ${ }^{4}$ Strobilurin fungicides with a broad spectrum are highly efficacious and are suitable for a wide range of crops. ${ }^{5}$ However, since the first launch of this class

\footnotetext{
${ }^{a}$ State Key Laboratory and Institute of Elemento-Organic Chemistry, Nankai University, Tianjin 300071, P. R. China. E-mail: fanzj@nankai.edu.cn; Tel: +86-13920714666

${ }^{b}$ Collaborative Innovation Center of Chemical Science and Engineering (Tianjin), Nankai University, Tianjin 300071, P. R. China

${ }^{c}$ The Ural Federal University Named after the First President of Russia B. N. Yeltsin, Yeltsin UrFU 620002, Ekaterinburg, Russia.E-mail:v.a.bakulev@urfu.ru

$\dagger$ Electronic supplementary information (ESI) available: X-ray crystal structure data of compound $\mathbf{6 d}$, characterization and copies of NMR spectra for all target compounds 6 and 8. CCDC 1509531. For ESI and crystallographic data in CIF or other electronic format see DOI: 10.1039/c6ra25520e
}

of fungicide, widespread applications have led to pathogen resistance. ${ }^{6}$ Resistant cases of Septoria in European wheat and the U.S. turf market were good examples. ${ }^{7}$ Therefore, new strobilurins are possibly needed for future markets.

Heterocyclic compounds exhibit wide spectrum of biological activity. ${ }^{8}$ Isothiazoles constitute a relatively novel class of heterocyclic compounds. As one of their members, 3,4dichloroisothiazoles possess a broad spectrum of biological activity such as insecticide, fungicide and potential systemic acquired resistance activities, 3,4-dichloroisothiazole-5carboxylic acid and its' derivatives manifest fungicidal activity; ${ }^{9}$ isotianil being as its' derivative was developed as a novel fungicide with activating defence responses against a wide range of plant pathogens. ${ }^{10}$

The purpose of this study was to use strobilurin A as a template to design and synthesize new strobilurin analogs (Fig. 1) with a active substructure of 3,4-dichloroisothiazole. Extensive biological assays demonstrated that newly synthesized compounds displayed good to excellent activity against one or multiple plant pathogens. Field trials suggested that the fungicidal activity of the best candidate 8d was better than commercial standards.

\section{Results and discussion}

\section{Chemistry}

The synthetic route of $\mathbf{3 a}$ and $\mathbf{3} \mathbf{c}$ was outlined in Scheme 1. Compound 2 was obtained in a high yield from compound 1 by ref. 11. Then compound 3a was obtained from compound 2 through substitution reaction. Compound $\mathbf{3 b}$ was prepared 


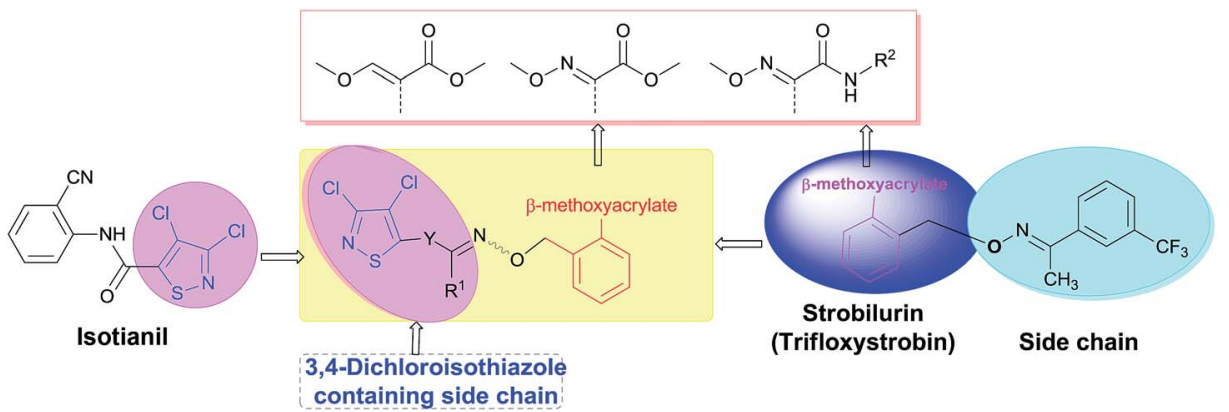

Fig. 1 Design of the title compounds.

from the oxidation of 3,4-dichloro-5-hydroxylmethyl isothiazole. Compound $3 \mathbf{c}$ was obtained by aldol condensation reaction between compound $\mathbf{3 b}$ and acetone.

For the target compounds synthesis, compounds $\mathbf{6 a - 6 h}$ were prepared by intermediates $\mathbf{3 a - 3 d}$ reacting with compounds $\mathbf{5 a}$ or $\mathbf{5 b}$ respectively (Table 1 ). ${ }^{12}$ Compounds $\mathbf{8 a}-\mathbf{8 r}$ were synthesized according to the method described in Table 2.

Compounds 7 series were obtained by hydrolytic reaction from the corresponding compounds $\mathbf{6 b}$, $\mathbf{6 f}$ or $\mathbf{6 h}$, and then compounds 8 series were obtained by the reaction of the corresponding compound 7 with a corresponding amino compound. The structures of the synthesized compounds were confirmed by ${ }^{1} \mathrm{H}$ NMR, ${ }^{13} \mathrm{C}$ NMR, HRMS or elemental analyses.

\section{Fungicidal activity}

The result of in vitro fungicidal activity determination of all synthesized compounds and the positive control azoxystrobin against 9 fungi was assessed at $50 \mu \mathrm{g} \mathrm{mL}{ }^{-1}$. The results were shown in Table 3.

For each fungus, most of the synthesized compounds were more active than the positive control azoxystrobin under the same condition. Especially for BC, SS and RC, majority of synthesized compounds exhibited better activity than azoxystrobin. For PI, most compounds showed similar or better activity than azoxystrobin except for compounds $\mathbf{8 m}$, 80 and compounds with a sulfur atom in the substitution of $\mathrm{R}^{2}$. Besides, for compounds $\mathbf{8 a - 8 r}$, it was also found that the compounds with a methyl group at $\mathrm{R}^{2}$ exhibited better activity. Compounds $\mathbf{8 d}, \mathbf{8 j}$ and $\mathbf{8 p}$ exhibited $100 \%$ inhibition activity

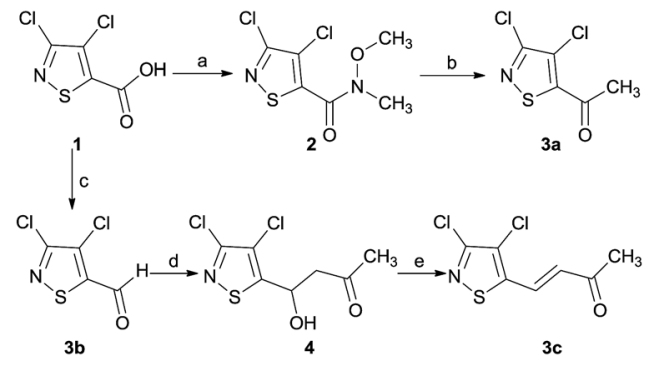

Scheme 1 Reagents: (a) $\mathrm{EDCl}, \mathrm{CH}_{3} \mathrm{NHOCH}_{3} \cdot \mathrm{HCl}, \mathrm{CH}_{2} \mathrm{Cl}_{2}, \mathrm{rt}$; (b) $\mathrm{CH}_{3} \mathrm{MgBr}, \mathrm{THF},-30^{\circ} \mathrm{C}$; (c) (i): $\mathrm{SOCl}_{2}, \mathrm{CH}_{3} \mathrm{OH}$; (ii): $\mathrm{NaBH}_{4}, \mathrm{CH}_{3} \mathrm{OH}$; (iii): PCC; (d) acetone $/ \mathrm{H}_{2} \mathrm{O}, \mathrm{NaOH}$; (e) $\mathrm{SOCl}_{2}, \mathrm{DMF}, 25^{\circ} \mathrm{C}$. against GZ, while they had higher activity than azoxystrobin against RC. Furthermore, compounds $\mathbf{6 d - 6 g}$ and $8 \mathbf{d}$ showed a broad spectrum of fungicidal activity in vitro. Overall, the in vitro fungicidal potency and spectrum are dependent on the individual structures, or substitutions (e.g., $\mathrm{X}, \mathrm{Y}, \mathrm{R}^{1}$, or $\left.\mathrm{R}^{2}\right)$ in the structures of the compounds $\mathbf{6}$ or $\mathbf{8}$ series.

In order to explore the fungicidal potency, precision toxicity determination for the $\mathrm{EC}_{50}$ of compounds $\mathbf{6 d - 6 g}$, 8d and $\mathbf{8 p}$ with a broader fungicidal spectrum described above were further conducted. The results in Table 4 indicated that compound 8d exhibited excellent activity with $\mathrm{EC}_{50}$ of $0.07 \mu \mathrm{g}$ $\mathrm{mL}^{-1}$ and $0.49 \mu \mathrm{g} \mathrm{mL}^{-1}$ against RC and PI, respectively; they were at the same level as that of the positive control azoxystrobin. Besides, compound $\mathbf{8 d}$ showed higher activity against $\mathrm{GZ}$ and $\mathrm{BC}$ with much lower $\mathrm{EC}_{50}$ than azoxystrobin. Compound 8d was confirmed with broad spectrum of fungicide activity by this precision toxicity experiments.

The in vivo fungicidal activity of all compounds and positive control (i.e., azoxystrobin) against P. cubensis, E. graminis, $P$. sorghi Schw and C. lagenarium were further assessed at $400 \mu \mathrm{g}$ $\mathrm{mL}^{-1}$ and the results were listed in Table 5. Most of the synthesized compounds were more active than azoxystrobin. For $P$. cubensis, the compounds $\mathbf{6 a}, \mathbf{6 d}, \mathbf{6 f}, \mathbf{8 d}$ and $8 \mathbf{r}$ exhibited

Table 1 General synthetic route of title compounds $6 a-6 h$

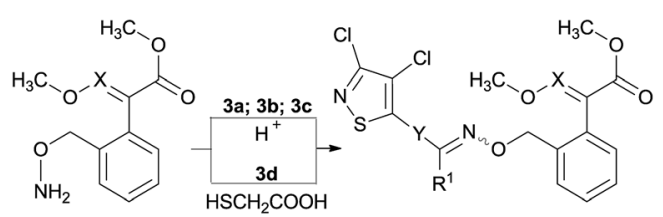

$5 \mathbf{a}(\mathrm{X}=\mathrm{CH}), \mathbf{5 b}(\mathrm{X}=\mathrm{N}) \quad 6 \mathbf{a}-6 \mathbf{h} \quad(\mathrm{X}=\mathrm{CH}, \mathrm{N})$

\begin{tabular}{llll}
\hline Compd & $\mathrm{X}$ & $\mathrm{R}^{1}$ & $\mathrm{Y}$ \\
\hline $\mathbf{6 a}$ & $\mathrm{CH}$ & $\cdots \mathrm{CH}_{3}$ & Covalent bond \\
$\mathbf{6 c}$ & $\mathrm{CH}$ & $\cdots \mathrm{H}$ & Covalent bond \\
$\mathbf{6 e}$ & $\mathrm{CH}$ & $\cdots \mathrm{NH}_{2}$ & Covalent bond \\
$\mathbf{6 g}$ & $\mathrm{CH}$ & $\cdots \mathrm{CH}_{3}$ & \\
$\mathbf{6 b}$ & $\mathrm{N}$ & $\cdots \mathrm{CH}_{3}$ & Covalent bond \\
$\mathbf{6 d}$ & $\mathrm{N}$ & $\cdots \mathrm{H}$ & Covalent bond \\
$\mathbf{6 f}$ & $\mathrm{N}$ & $\cdots \mathrm{NH}_{2}$ & Covalent bond \\
$\mathbf{6 h}$ & $\mathrm{N}$ & $\cdots \mathrm{CH}_{3}$ & $\cdots$
\end{tabular}


Table 2 General synthetic route of title compounds $8 a-8 r$

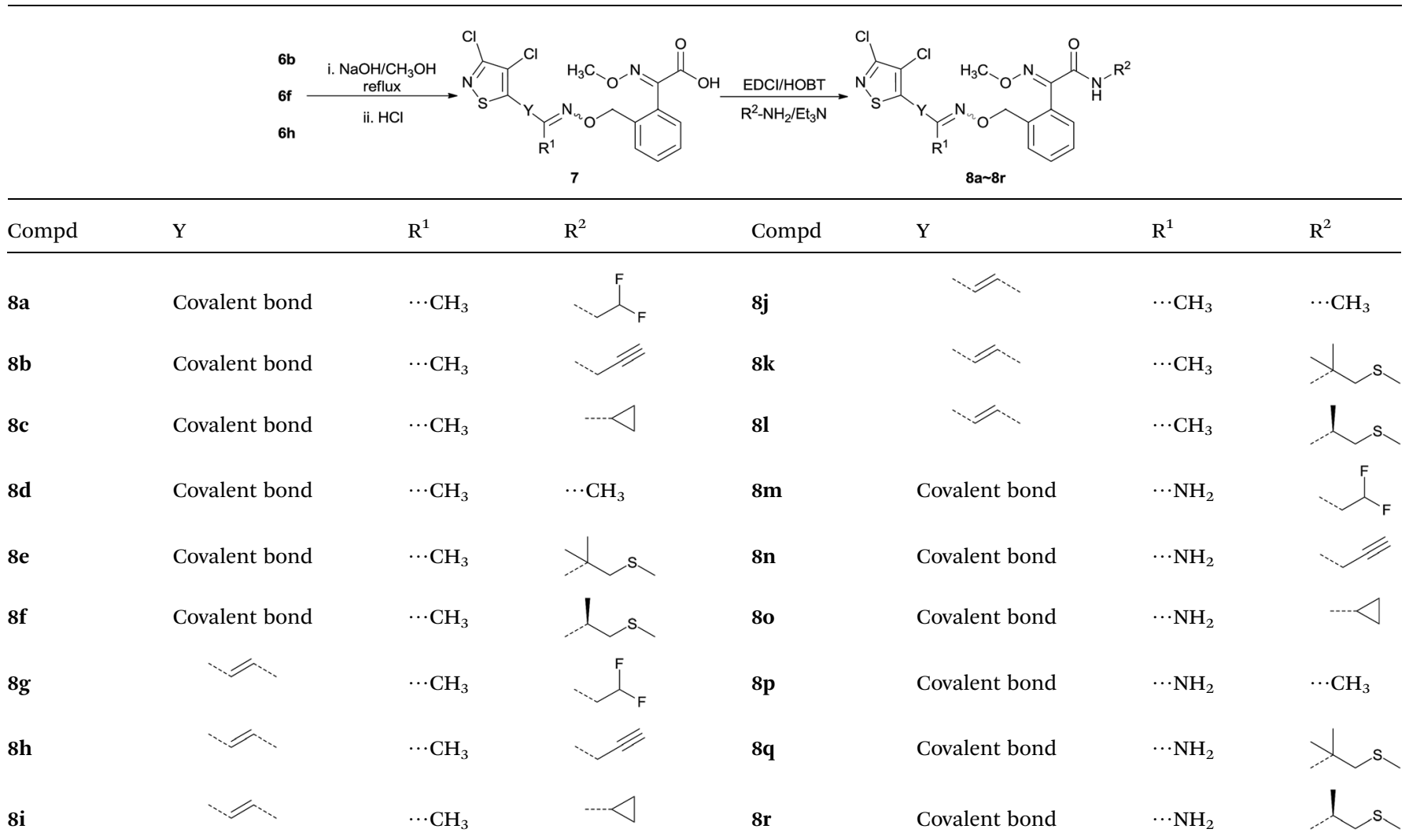

almost $100 \%$ activity which were better than azoxystrobin (with only $85 \%$ of activity). Besides, the compounds $6 \mathbf{6}-\mathbf{6 g}, \mathbf{8 d}, \mathbf{8 g}, \mathbf{8 h}$, 8 and azoxystrobin showed the similar $100 \%$ activity against $E$. graminis. Even though azoxystrobin showed no activity against P. sorghi Schw, the compounds $\mathbf{6 b}, \mathbf{6 d}, \mathbf{6 f}, \mathbf{6 g}, \mathbf{8 a}$ and $8 \mathbf{b}$ exhibited $100 \%$ activity. Furthermore, almost all of the compounds except for $\mathbf{6 b}, \mathbf{6 h}$ and $\mathbf{8 e}$ had similar to or better activity than azoxystrobin against $C$. lagenarium. Thus, the compounds 6a-6g, 8b and 8d were confirmed as with broadspectrum of fungicidal activity in vivo too. Afterwards, 6a, 6d, 6g, 6f, 8b and 8d with good activity were further validated at concentrations of $50 \mu \mathrm{g} \mathrm{mL}{ }^{-1}, 12.5 \mu \mathrm{g} \mathrm{mL}^{-1}, 3.13 \mu \mathrm{g} \mathrm{mL}^{-1}, 0.78$ $\mu \mathrm{g} \mathrm{mL} \mathrm{m}^{-1}$ and $0.20 \mu \mathrm{g} \mathrm{mL}^{-1}$ in vivo, respectively. The results were shown in Table 6.

As can be seen from Table 6, compounds 6a, 6d, $\mathbf{6 f}, \mathbf{8 b}$ and $\mathbf{8 d}$ exhibited $90-100 \%$ inhibition activity against $E$. graminis even at $0.20 \mu \mathrm{g} \mathrm{mL} \mathrm{m}^{-1}$, which were similar to that of positive control trifloxystrobin (with inhibition of 95\%) and were much better than enestroburin (with inhibition of $30 \%$ ). The compound $\mathbf{6 a}$ exhibited best activity against $P$. sorghi Schw as the same as positive control trifloxystrobin, they both had $95 \%$ of fungicidal activity at $0.2 \mu \mathrm{g} \mathrm{mL}^{-1}$; their activities were much better than that of enestroburin (only $30 \%$ at $0.20 \mu \mathrm{g} \mathrm{mL}^{-1}$ ). The compounds $6 \mathbf{a}$ and $\mathbf{8 d}$ exhibited best activity against $C$. lagenarium as the same as positive control trifloxystrobin and enestroburin, they all had about $65 \%$ of activity even at $0.20 \mu \mathrm{g} \mathrm{mL}^{-1}$. Most importantly, the compound $\mathbf{8 d}$ also exhibited very good activity against $P$. cubensis with $20 \%$ of inhibition at $0.20 \mu \mathrm{g} \mathrm{mL} \mathrm{m}^{-1}$, while the two positive controls trifloxystrobin and enestroburin had no activity against P. cubensis even at $12.5 \mu \mathrm{g} \mathrm{mL} \mathrm{m}^{-1}$. Our in vivo confirmation studies indicated, most of the active compounds discovered not only kept its' highly activity, but also acted to a broad spectrum of fungi tested. Compound 8d deserved for further novel fungicide development studies as a candidate.

\section{Field efficacy evaluation of compound 8d}

The results of the field experiments were shown in Table 7. Studies indicated that the compound 8d exhibited significantly better efficacy $(78.62 \%)$ against cucumber $S$. fuliginea than commercial standards (i.e., azoxystrobin and trifloxystrobin) at the same application rate of $37.5 \mathrm{~g}$ ai per $\mathrm{hm}^{2}$ at 21 days after spraying application. At an application rate of $75 \mathrm{~g}$ ai per $\mathrm{hm}^{2}$, the compound 8d showed similar activity against $P$. cubensis as one commercial standard pyraclostrobin, but significantly better than another commercial standard trifloxystrobin. These results suggested that the compound $\mathbf{8 d}$ could be considered as an alternative to control $S$. fuliginea and $P$. cubensis, it is under further novel pesticide development studies.

\section{Experimental}

\section{Equipment and materials}

Melting points of all compounds were determined on an X-4 binocular microscope (Gongyi Tech. Instrument Co., Henan, 
China) and the thermometer was not corrected. Proton NMR spectra were obtained using a Bruker AVANCE-400 MHz spectrometer and chemical shift values $(\delta)$ were reported in ppm with deutero-chloroform $\left(\mathrm{CDCl}_{3}\right)$ as a solvent and tetramethylsilane (TMS) as an internal standard. High resolution mass spectrometry (HRMS) data were obtained on an FTICR-MS Varian 7.0T FTICR-MS instrument. Elemental analyses were taken on a Vario EL III elemental analysis instrument. Crystal structure was recorded by Bruker SMART 1000 CCD diffraction meter. All solvents and reagents were an analytical reagent grade. Column chromatography purification was carried out on silica gel.

\section{General procedure for the synthesis of compound $3 \mathrm{a}$}

3,4-Dichloro- $N$-methoxy- $N$-methylisothiazole-5-carboxamide 2 can be prepared from 3,4-dichloroisothiazole-5-carboxylic acid 1 according to the revising procedures of ref. 11 . To a solution of the compound 2 (3.00 g, $12.44 \mathrm{mmol})$ in anhydrous tetrahydrofuran $(45 \mathrm{~mL})$ at $-30{ }^{\circ} \mathrm{C}$ under $\mathrm{N}_{2}$ atmosphere was added dropwise with a solution of methyl magnesium bromide in $\mathrm{Et}_{2} \mathrm{O}$ (3 $\mathrm{mol} \mathrm{L}^{-1}, 5.81 \mathrm{~mL}, 17.42 \mathrm{mmol}$ ). Then the mixture was allowed to stir at $-30{ }^{\circ} \mathrm{C}$ for $1 \mathrm{~h}$ and room temperature for another $1 \mathrm{~h}$. When the reaction completed, the reaction mixture was worked-up by the sat. aq. $\mathrm{NH}_{4} \mathrm{Cl}(50 \mathrm{~mL})$. After removal of the tetrahydrofuran under vacuum, the aqueous phase was extracted with ethyl acetate $(3 \times 50 \mathrm{~mL})$. The organic layers were combined, washed with water $(50 \mathrm{~mL})$ and saturated brine $(50$ $\mathrm{mL}$ ), and then dried over anhydrous sodium sulfate. After

Table 3 In vitro fungicidal activity of compounds $6 a-6 h$ and $8 a-8 r$ at $50 \mu \mathrm{g} \mathrm{mL}-1$

\begin{tabular}{|c|c|c|c|c|c|c|c|c|c|}
\hline Compd & $\mathrm{AS}$ & $\mathrm{CA}$ & $\mathrm{GZ}$ & $\mathrm{PP}$ & $\mathrm{BC}$ & SS & $\mathrm{RC}$ & PS & PI \\
\hline $6 a$ & 43 & 67 & 52 & 78 & 100 & 80 & 100 & 65 & 53 \\
\hline $6 b$ & 47 & 50 & 41 & 53 & 100 & 100 & 85 & 77 & 79 \\
\hline $6 c$ & 57 & 67 & 74 & 78 & 100 & 53 & 100 & 65 & 58 \\
\hline $6 d$ & 100 & 92 & 71 & 62 & 100 & 90 & 98 & 69 & 95 \\
\hline $6 e$ & 57 & 100 & 61 & 87 & 100 & 100 & 100 & 59 & 47 \\
\hline $6 f$ & 53 & 75 & 50 & 71 & 100 & 98 & 89 & 77 & 89 \\
\hline $6 g$ & 57 & 50 & 74 & 74 & 100 & 100 & 100 & 71 & 79 \\
\hline $6 h$ & 36 & 50 & 61 & 48 & 100 & 87 & 81 & 59 & 47 \\
\hline $8 a$ & 37 & 43 & 79 & 40 & 54 & 84 & 88 & 20 & 80 \\
\hline $8 b$ & 29 & 36 & 100 & 49 & 52 & 100 & 87 & 73 & 80 \\
\hline $8 c$ & 28 & 44 & 64 & 61 & 47 & 80 & 61 & 57 & 100 \\
\hline 8d & 48 & 68 & 100 & 72 & 100 & 67 & 100 & 89 & 100 \\
\hline $8 e$ & 27 & 46 & 52 & 43 & 63 & 29 & 76 & 21 & 29 \\
\hline $8 f$ & 16 & 13 & 33 & 33 & 46 & 53 & 76 & 15 & 17 \\
\hline $8 g$ & 34 & 36 & 45 & 30 & 53 & 53 & 85 & 35 & 90 \\
\hline $8 \mathrm{~h}$ & 41 & 52 & 82 & 65 & 47 & 80 & 100 & 78 & 100 \\
\hline $8 \mathrm{i}$ & 48 & 60 & 64 & 72 & 58 & 73 & 71 & 68 & 100 \\
\hline $8 \mathbf{j}$ & 54 & 84 & 100 & 65 & 84 & 73 & 85 & 89 & 100 \\
\hline 8k & 5 & 13 & 24 & 40 & 32 & 41 & 58 & 15 & 11 \\
\hline 81 & 13 & 13 & 61 & 58 & 43 & 53 & 62 & 21 & 20 \\
\hline $8 \mathrm{~m}$ & 13 & 17 & 33 & 40 & 38 & 53 & 62 & 24 & 23 \\
\hline $8 n$ & 8 & 20 & 55 & 19 & 42 & 47 & 66 & 46 & 100 \\
\hline 80 & 21 & 28 & 64 & 23 & 37 & 73 & 85 & 19 & 33 \\
\hline $8 p$ & 34 & 44 & 100 & 40 & 58 & 67 & 100 & 84 & 100 \\
\hline $8 q$ & 16 & 13 & 21 & 28 & 39 & 53 & 62 & 15 & 17 \\
\hline $8 r$ & 9 & 17 & 45 & 11 & 36 & 53 & 54 & 21 & 11 \\
\hline Azoxystrobin & 75 & 81 & 71 & 100 & 91 & 100 & 100 & 81 & \\
\hline
\end{tabular}

Table $4 \quad E_{50}$ of compounds $6 \mathrm{~d}-6 \mathrm{~g}$ and $8 \mathrm{~d}$

\begin{tabular}{llllllll}
\hline Compd & AS & CA & GZ & BC & SS & RC & PI \\
\hline 6d & $33.34^{a}$ & 14.47 & nd $^{b}$ & 2.94 & 5.21 & 0.13 & 3.10 \\
$\mathbf{6 e}$ & nd & 58.25 & nd & 12.15 & 20.06 & 0.21 & nd \\
$\mathbf{6 f}$ & nd & nd & nd & 1.62 & 7.53 & nd & nd \\
$\mathbf{6 g}$ & nd & nd & nd & 3.93 & 4.47 & 0.11 & nd \\
$\mathbf{8 d}$ & nd & nd & 1.75 & 0.15 & nd & 0.07 & 0.49 \\
$\mathbf{8 p}$ & nd & nd & 1.81 & nd & nd & 0.69 & 3.84 \\
Azoxystrobin & 185.42 & 2.50 & 6.92 & 6.31 & 4.04 & 0.06 & 0.40
\end{tabular}

${ }^{a}$ Determined values based on the results shown in Table $3 .{ }^{b}$ nd, not detect.

filtration, the solvent was evaporated. The residue was then purified by column chromatography on silica gel using ethyl acetate and petroleum ether $\left(60-90^{\circ} \mathrm{C}\right)$ with $1: 9$ of $v / v$ as an eluent to obtain yellow oil $3 \mathrm{a}(1.56 \mathrm{~g})$ in a yield of $63.8 \% .{ }^{1} \mathrm{H}$ $\operatorname{NMR}\left(400 \mathrm{MHz}, \mathrm{CDCl}_{3}\right) \delta 2.65\left(\mathrm{~s}, 3 \mathrm{H}, \mathrm{O}=\mathrm{C}-\mathrm{CH}_{3}\right)$.

\section{General procedure for the synthesis of compound $3 \mathbf{b}$}

A solution of (3,4-dichloroisothiazol-5-yl)methanol (1.37 g, 7.44 mmol), which can be prepared from 3,4-dichloroisothiazole-5-

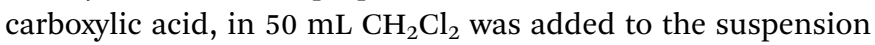
of PCC $(2.40 \mathrm{~g}, 11.16 \mathrm{mmol})$ and diatomite $(2.40 \mathrm{~g})$ in $50 \mathrm{~mL}$ $\mathrm{CH}_{2} \mathrm{Cl}_{2}$ at $0{ }^{\circ} \mathrm{C}$, then the reaction mixture was allowed to stir at

Table 5 Preventive fungicidal in vivo activities of compounds $6 \mathrm{a}-6 \mathrm{~h}$ and $8 \mathrm{a}-8 \mathrm{r}$ at $400 \mu \mathrm{g} \mathrm{m}^{-1}$

\begin{tabular}{lllll}
\hline & & & & P. sorghi \\
Compd & $P$. cubensis & E. graminis & Schw & C. lagenarium \\
\hline $\mathbf{6 a}$ & 100 & 100 & 0 & 98 \\
$\mathbf{6 b}$ & 0 & 100 & 100 & 100 \\
$\mathbf{6 c}$ & 85 & 100 & 0 & 98 \\
$\mathbf{6 d}$ & 99 & 100 & 100 & 100 \\
$\mathbf{6 e}$ & 85 & 100 & 85 & 50 \\
$\mathbf{6 f}$ & 98 & 100 & 100 & 80 \\
$\mathbf{6 g}$ & 85 & 100 & 100 & 100 \\
$\mathbf{6 h}$ & 30 & 0 & 50 & 0 \\
$\mathbf{8 a}$ & 75 & 50 & 100 & 98 \\
$\mathbf{8 b}$ & 85 & 100 & 100 & 100 \\
$\mathbf{8 c}$ & 0 & 30 & 70 & 85 \\
$\mathbf{8 d}$ & 100 & 100 & 0 & 80 \\
$\mathbf{8 e}$ & 70 & 80 & 40 & 0 \\
$\mathbf{8 f}$ & 40 & 0 & 0 & 85 \\
$\mathbf{8 g}$ & 0 & 100 & 40 & 85 \\
$\mathbf{8 h}$ & 0 & 100 & 40 & 100 \\
$\mathbf{8 i}$ & 0 & 0 & 60 & 98 \\
$\mathbf{8 j}$ & 0 & 60 & 0 & 100 \\
$\mathbf{8 k}$ & 85 & 0 & 0 & 80 \\
$\mathbf{8 1}$ & 60 & 0 & 60 & 100 \\
$\mathbf{8 m}$ & 80 & 0 & 0 & 98 \\
$\mathbf{8 n}$ & 60 & 0 & 80 & 100 \\
$\mathbf{8 0}$ & 85 & 0 & 40 & 80 \\
$\mathbf{8 p}$ & 70 & 100 & 80 & 85 \\
$\mathbf{8 q}$ & 85 & 0 & 0 & 100 \\
$\mathbf{8 r}$ & 100 & 0 & 0 & 80 \\
Azoxystrobin & 85 & 100 & 0 & 80 \\
& & & &
\end{tabular}


room temperature for overnight. The reaction mixture was filtrated and the solvent was evaporated. The residue was then purified by column chromatography on silica gel using ethyl acetate and petroleum ether $\left(60-90{ }^{\circ} \mathrm{C}\right)$ with $1: 10$ of $v / v$ as an eluent to afford the white solid $3 \mathbf{b}(0.89 \mathrm{~g})$ in a yield of $65.9 \% .{ }^{1} \mathrm{H}$ $\operatorname{NMR}\left(400 \mathrm{MHz}, \mathrm{CDCl}_{3}\right) \delta 10.09(\mathrm{~s}, \mathrm{O}=\mathrm{CH})$.

\section{General procedure for the synthesis of compound $3 \mathrm{c}$}

To a solution of $3 \mathbf{b}(0.10 \mathrm{~g}, 0.05 \mathrm{mmol})$ in $9 \mathrm{~mL}$ acetone was added $1 \mathrm{~mL}$ water, then $0.15 \mathrm{~mL}$ of aqueous $\mathrm{NaOH}(2 \%)$ was added dropwise within $30 \mathrm{~s}$ at ice bath. The reaction mixture was stirred at this temperature for about $2 \mathrm{~min}$ and then was quenched with $0.50 \mathrm{~mL}$ dilute hydrochloric acid $\left(1 \mathrm{~mol} \mathrm{~L}^{-1}\right)$. After removal of the acetone under vacuum, water $(20 \mathrm{~mL})$ was added and the aqueous phase was extracted with ethyl acetate (2 $\times 10 \mathrm{~mL}$ ). The organic layers were combined and washed with

Table 6 Fungicidal activity validation studies in vivo

\begin{tabular}{|c|c|c|c|c|c|}
\hline Compd & $\begin{array}{l}C \\
\left(\mu \mathrm{g} \mathrm{mL}^{-1}\right)\end{array}$ & $\begin{array}{l}P . \\
\text { cubensis }\end{array}$ & $\begin{array}{l}\text { E. } \\
\text { graminis }\end{array}$ & $\begin{array}{l}\text { P. sorghi } \\
\text { Schw }\end{array}$ & $\begin{array}{l}\text { C. } \\
\text { lagenarium }\end{array}$ \\
\hline \multirow[t]{5}{*}{$6 a$} & 0.2 & 0 & 100 & 95 & 65 \\
\hline & 0.78 & 0 & 100 & 95 & 70 \\
\hline & 3.13 & 0 & 100 & 98 & 80 \\
\hline & 12.5 & 0 & 100 & 100 & 90 \\
\hline & 50 & 0 & 100 & 100 & 98 \\
\hline \multirow[t]{5}{*}{$6 d$} & 0.2 & 0 & 100 & 0 & 0 \\
\hline & 0.78 & 0 & 100 & 0 & 0 \\
\hline & 3.13 & 0 & 100 & 30 & 0 \\
\hline & 12.5 & 0 & 100 & 45 & 15 \\
\hline & 50 & 0 & 100 & 70 & 40 \\
\hline \multirow[t]{5}{*}{$6 \mathrm{~g}$} & 0.2 & 0 & 30 & 0 & 0 \\
\hline & 0.78 & 0 & 45 & 0 & 0 \\
\hline & 3.13 & 0 & 65 & 0 & 0 \\
\hline & 12.5 & 0 & 90 & 0 & 0 \\
\hline & 50 & 0 & 100 & 30 & 0 \\
\hline \multirow[t]{5}{*}{$6 f$} & 0.2 & 0 & 100 & 0 & 0 \\
\hline & 0.78 & 0 & 100 & 0 & 0 \\
\hline & 3.13 & 0 & 100 & 20 & 0 \\
\hline & 12.5 & 0 & 100 & 55 & 0 \\
\hline & 50 & 0 & 100 & 80 & 0 \\
\hline \multirow[t]{5}{*}{$8 b$} & 0.2 & 0 & 95 & 0 & 0 \\
\hline & 0.78 & 0 & 100 & 0 & 0 \\
\hline & 3.13 & 0 & 100 & 0 & 0 \\
\hline & 12.5 & 0 & 100 & 0 & 0 \\
\hline & 50 & 0 & 100 & 0 & 0 \\
\hline \multirow[t]{5}{*}{$8 d$} & 0.2 & 20 & 90 & 10 & 60 \\
\hline & 0.78 & 30 & 95 & 45 & 70 \\
\hline & 3.13 & 45 & 100 & 85 & 85 \\
\hline & 12.5 & 55 & 100 & 90 & 95 \\
\hline & 50 & 65 & 100 & 95 & 100 \\
\hline \multirow[t]{5}{*}{ Trifloxystrobin } & 0.2 & 0 & 95 & 95 & 65 \\
\hline & 0.78 & 0 & 100 & 98 & 85 \\
\hline & 3.13 & 0 & 100 & 100 & 98 \\
\hline & 12.5 & 0 & 100 & 100 & 98 \\
\hline & 50 & 20 & 100 & 100 & 100 \\
\hline \multirow[t]{5}{*}{ Enestroburin } & 0.2 & 0 & 30 & 30 & 65 \\
\hline & 0.78 & 0 & 65 & 75 & 85 \\
\hline & 3.13 & 0 & 95 & 98 & 95 \\
\hline & 12.5 & 0 & 98 & 100 & 98 \\
\hline & 50 & 0 & 100 & 100 & 100 \\
\hline
\end{tabular}

saturated brine $(50 \mathrm{~mL})$, dried over anhydrous sodium sulfate. After filtration, the solvent was evaporated. The residue was then purified by column chromatography on silica gel using ethyl acetate and petroleum ether $\left(60-90^{\circ} \mathrm{C}\right)$ with $1: 10$ of $v / v$ as an eluent to afford the white solid intermediate $4(0.10 \mathrm{~g})$ in a yield of $75.9 \% .{ }^{1} \mathrm{H}$ NMR $\left(400 \mathrm{MHz}, \mathrm{CDCl}_{3}\right) \delta 5.43(\mathrm{~d}, J=8.8 \mathrm{~Hz}$, $1 \mathrm{H}, \mathrm{O}-\mathrm{CH}), 4.00(\mathrm{~s}, 1 \mathrm{H}, \mathrm{OH}), 3.14(\mathrm{~d}, J=17.7 \mathrm{~Hz}, 1 \mathrm{H}, \mathrm{O}=\mathrm{C}-$ $\left.\mathrm{CH}_{2}\right), 2.81\left(\mathrm{dd}, J=18.1,9.6 \mathrm{~Hz}, 1 \mathrm{H}, \mathrm{O}=\mathrm{C}-\mathrm{CH}_{2}\right), 2.24(\mathrm{~s}, 3 \mathrm{H}, \mathrm{O}=$ $\left.\mathrm{C}-\mathrm{CH}_{3}\right)$.

To a solution of intermediate $4(0.10 \mathrm{~g}, 0.42 \mathrm{mmol})$ in anhydrous $\mathrm{CH}_{2} \mathrm{Cl}_{2}(20 \mathrm{~mL})$, and $\mathrm{SOCl}_{2}(0.1 \mathrm{~g}, 0.84 \mathrm{mmol})$ was added and followed by a catalytic amount of DMF. The reaction mixture was allowed to stir at $25{ }^{\circ} \mathrm{C}$ for $24 \mathrm{~h}$. The solvent was evaporated under reduced pressure and the residue was then purified by column chromatography on silica gel using ethyl acetate and petroleum ether $\left(60-90^{\circ} \mathrm{C}\right)$ with $1: 5$ of $v / v$ as an eluent to afford the white solid $3 \mathrm{c}(0.08 \mathrm{~g})$ in a yield of $88.9 \% .{ }^{1} \mathrm{H}$ NMR $\left(400 \mathrm{MHz}, \mathrm{CDCl}_{3}\right) \delta 7.49(\mathrm{~d}, J=16.4 \mathrm{~Hz}, 1 \mathrm{H}, \mathrm{CH}=\mathrm{CH})$, $6.71(\mathrm{~d}, J=16.3 \mathrm{~Hz}, 1 \mathrm{H}, \mathrm{CH}=\mathrm{CH}), 2.39\left(\mathrm{~s}, 3 \mathrm{H}, \mathrm{C}=\mathrm{C}-\mathrm{CH}_{3}\right)$.

\section{General procedure for the synthesis of compounds $6 a-6 d$ and 6g-6h}

Compounds $5 \mathbf{a}$ and $\mathbf{5 b}$ can be prepared following the procedure reported by ref. 13. A solution of compound $\mathbf{5 a}$ or $\mathbf{5 b}(1.12$ $\mathrm{mmol}$ ) in $15 \mathrm{~mL}$ ethanol was add to the solution of intermediates $3 \mathbf{a}, 3 \mathbf{b}$ or $3 \mathbf{c}(1.02 \mathrm{mmol})$ in ethanol $(15 \mathrm{~mL})$, and the reaction mixture was added the catalytic amount of $2 \mathrm{~mol} \mathrm{~L}^{-1}$ hydrochloric acid and stirred at room temperature for overnight. The solvent was evaporated under reduced pressure and the residue was then purified by recrystallization in ethanol or column chromatography on silica gel using ethyl acetate and petroleum ether $\left(60-90^{\circ} \mathrm{C}\right)$ with $1: 9$ to $1: 4$ of $v / v$ as an eluent to obtain the desired derivatives 6 (Table 1 ).

\section{General procedure for the synthesis of compounds $6 \mathrm{e}$ and $6 \mathrm{f}$}

Compounds $6 \mathbf{e}$ and $\mathbf{6 f}$ can be prepared following the procedure reported by ref. 13. A solution of compounds $5 \mathbf{a}$ or $5 \mathbf{b}(1.22$ $\mathrm{mmol}$ ) in $15 \mathrm{~mL}$ ethanol was added to the solution of commercially available 3,4-dichloroisothiazole-5-carbonitrile $3 d(0.20 \mathrm{~g}, 1.11 \mathrm{mmol})$ in ethanol $(15 \mathrm{~mL}), 2$-mercaptoacetic acid $(0.10 \mathrm{~g}, 1.09 \mathrm{mmol})$ was added to the reaction mixture for stirring at room temperature for overnight. The solvent was evaporated under reduced pressure and the residue was then purified by recrystallization in ethyl acetate or column chromatography on silica gel using ethyl acetate and petroleum ether $\left(60-90{ }^{\circ} \mathrm{C}\right)$ with $1: 4$ to $1: 9$ of $v / v$ as an eluent to give the desired derivatives (Table 1).

\section{General procedure for the synthesis of compounds 7}

Intermediates $\mathbf{6 b}, \mathbf{6 f}$ or $\mathbf{6 h}(2.49 \mathrm{mmol})$ was dissolved in $15 \mathrm{~mL}$ methanol, the solution of sodium hydroxide $(0.30 \mathrm{~g}, 7.47 \mathrm{mmol})$ in $15 \mathrm{~mL}$ methanol was added to the reaction mixture for 30 min of refluxing. After completing of the reaction, the solvent was evaporated under reduced pressure and the residue was added $15 \mathrm{~mL}$ water. The aqueous phase was adjusted to $\mathrm{pH} 2-3$ with dilute hydrochloric acid $\left(3 \mathrm{~mol} \mathrm{~L}^{-1}\right)$. The aqueous layer was 
extracted with ethyl acetate $(2 \times 15 \mathrm{~mL})$. The organic layers were combined and washed with saturated brine $(50 \mathrm{~mL})$, dried over sodium sulfate. After filtration, the solvent was evaporated to obtain the compounds 7 as a white solid.

\section{General procedure for the synthesis of compounds 8a-8r}

The reaction mixture of the compound $7(0.75 \mathrm{mmol})$, EDCI $(0.17 \mathrm{~g}, 0.90 \mathrm{mmol})$, HOBT $(0.11 \mathrm{~g}, 0.77 \mathrm{mmol})$ in dichloromethane $(25 \mathrm{~mL})$ was stirred for $15 \mathrm{~min}$ in ice bath. A solution of amine in dichloromethane $(25 \mathrm{~mL})$ was added and followed by $\mathrm{Et}_{3} \mathrm{~N}(0.09 \mathrm{~g}, 0.90 \mathrm{mmol})$, the reaction mixture was stirred for further $16 \mathrm{~h}$. After completion of the reaction, the organic layer was successively washed with water $(2 \times 30 \mathrm{~mL})$ and saturated brine $(40 \mathrm{~mL})$, dried over $\mathrm{MgSO}_{4}$ and concentrated under vacuum. After filtration, the solvent was evaporated. The residue was then purified by column chromatography on silica gel using ethyl acetate and petroleum ether $\left(60-90^{\circ} \mathrm{C}\right)$ with $1: 2$ to $1: 5$ of $v / v$ as an eluent to give the desired derivatives (Table 2).

\section{Crystal structure determination for compound $\mathbf{6 d}$}

The crystal of compound $\mathbf{6 d}$ was obtained by recrystallization from ethanol (Fig. 2). X-ray intensity data were recorded on a Bruker SMART 1000 CCD diffraction meter using graphitemonochromatic Mo $\mathrm{K} \alpha$ radiation $(\lambda=0.71073 \AA)$. A total of 13757 reflections were measured, of which 3004 were unique $\left(R_{\text {int }}=0.0635\right)$ in the range of $3.06^{\circ} \leq \theta \leq 25.02^{\circ}(h,-13$ to $13 ; k$, -9 to $9 ; l,-22$ to 19$)$, and 2884 observed reflections with $I>2 \sigma(I)$ were used in the refinement on $F^{2}$. The structure was solved by direct methods with the SHELXS-97 program. All of the non-H atoms were refined anisotropically by full-matrix least-squares to give the final $R=0.0698$ and $w R=0.2049\left(w=1 /\left[\sigma^{2}\left(\left(F_{\mathrm{o}}{ }^{2}\right)+\right.\right.\right.$ $\left.(0.1200 P))^{2}+6.9197 P\right]$, where $P=\left({F_{\mathrm{o}}}^{2}+2{F_{\mathrm{c}}}^{2}\right) / 3$ with $(\Delta / \sigma)_{\max }=$ 0.981 and $S=1.061$ by using the SHELXL program. The hydrogen atoms were located from a difference Fourier map and refined isotropically.

\section{Fungicidal assay}

The preliminary in vitro fungicidal activities of newly synthesized compounds against Alternaria solani (AS), Botrytis cinerea

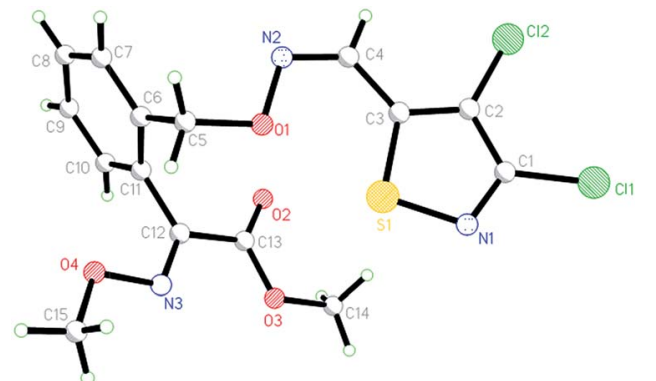

Fig. 2 X-ray diffraction structure of the title compound $6 \mathrm{~d}$.

(BC), Cercospora arachidicola (CA), Gibberella zeae (GZ), Phytophthora infestans (Mont) de Bary (PI), Physalospora piricola (PP), Pellicularia sasakii (PS), Sclerotinia sclerotiorum (SS), and Rhizoctonia cerealis (RC) were tested according to ref. 14. Precision toxicity studies were conducted for the median effective concentration $\left(\mathrm{EC}_{50}\right)$ calculation according to ref. 14 .

The preventive in vivo activities of the target compounds against Pseudoperonospora cubensis, Erysiphe graminis, Puccinia sorghi Schw and Colletotrichum lagenarium were tested in green house according to the ref. 15. For the active compounds, different lower concentration tests were also conducted for validation.

\section{Evaluation of field efficacy of compound 8d}

Due to well laboratory performance against fungi in vitro and in vivo, the compound $\mathbf{8 d}$ was employed to evaluate its efficacy in the cucumber field. A $9.60 \%$ EC of $8 d$ was prepared for the efficacy against $S$. fuliginea and P. cubensis in Wuqing County, Tianjin, P. R. China. Commercial available products of $250 \mathrm{~g}$ $\mathrm{L}^{-1}$ azoxystrobin SC, 50\% trifloxystrobin WG, $250 \mathrm{~g} \mathrm{~L}^{-1}$ pyraclostrobin EC were chosen as positive control. An application dosages of $\mathbf{8 d}$ and positive standards was 37.5 and $75 \mathrm{~g}$. ai per ha for $S$. fuliginea and $P$. cubensis, respectively. Disease index was evaluated by formula as DI $=\sum(A \times B) \times 100 /(C \times 9)$; $A$ means the number of disease leaf; $B$-means the corresponding grade of $A$; $C$-means the total number of investigation leaf. Prevention efficacy was calculated with a formula efficacy $(\%)=$ $\left[1-\mathrm{CK}_{0} \times \mathrm{PT}_{1} /\left(\mathrm{CK}_{1} \times \mathrm{PT}_{0}\right)\right] \times 100 \% ; \mathrm{CK}_{0}$-means DI of control

Table 7 Efficacy of compound 8d against two diseases in cucumber field (2015)

\begin{tabular}{|c|c|c|c|c|c|c|c|}
\hline \multirow[b]{2}{*}{ Disease } & \multirow[b]{2}{*}{ Compd } & \multirow{2}{*}{$\begin{array}{l}\text { Amount } \\
\left(\mathrm{g} \text { ai per } \mathrm{hm}^{2}\right)\end{array}$} & \multirow[b]{2}{*}{ Base DI ${ }^{a}$} & \multirow[b]{2}{*}{ After $\mathrm{DI}^{b}$} & \multirow[b]{2}{*}{ Efficacy (\%) } & \multicolumn{2}{|c|}{$\mathrm{DD}^{d}$} \\
\hline & & & & & & $5 \%$ & $1 \%$ \\
\hline \multirow[t]{4}{*}{ S. fuliginea } & $9.60 \% 8 d \mathrm{EC}$ & 37.5 & 1.98 & 8.01 & $78.62 \pm 4.38$ & $\mathrm{a}$ & A \\
\hline & $250 \mathrm{~g} \mathrm{~L}^{-1}$ azoxystrobin SC & 37.5 & 1.66 & 9.59 & $70.19 \pm 2.91$ & $\mathrm{~b}$ & $\mathrm{~B}$ \\
\hline & $50 \%$ trifloxystrobin WG & 37.5 & 1.64 & 10.04 & $68.02 \pm 5.58$ & $\mathrm{~b}$ & $\mathrm{~B}$ \\
\hline & CK & $\mathrm{nd}^{c}$ & 1.07 & 20.63 & nd & nd & nd \\
\hline \multirow[t]{4}{*}{ P. cubensis } & $9.60 \% 8 d \mathrm{EC}$ & 75 & 3.71 & 5.39 & $79.18 \pm 1.09$ & $\mathrm{a}$ & A \\
\hline & $50 \%$ trifloxystrobin WG & 75 & 3.73 & 7.24 & $72.02 \pm 2.15$ & $\mathrm{~b}$ & $\mathrm{~B}$ \\
\hline & $250 \mathrm{~g} \mathrm{~L}^{-1}$ pyraclostrobin EC & 75 & 3.57 & 5.78 & $77.02 \pm 1.77$ & $\mathrm{a}$ & $\mathrm{AB}$ \\
\hline & CK & $\mathrm{nd}^{c}$ & 3.58 & 24.96 & nd & nd & nd \\
\hline
\end{tabular}

${ }^{a}$ Base DI, base disease index. ${ }^{b}$ After DI, disease index after compounds application. ${ }^{c}$ nd, not need to detect. ${ }^{d}$ DD, distinct difference. 
group before applying water; $\mathrm{PT}_{0}$ means $\mathrm{DI}$ of treatment group before applying compound; $\mathrm{CK}_{1}$ means DI of control group after applying water; $\mathrm{PT}_{1}$ means DI of treatment group after applying compound. Duncan's new multiple range (DMRT) statistic method was used for data analysis.

\section{Conclusion}

A series of strobilurin analogues with a substructure of 3,4dichloroisothiazole were synthesized and characterized by NMR, HRMS and X-ray diffraction. These compounds were assessed for biological activity against a few important plant fungi in vitro and in vivo. The fungicidal potency and spectrum varied with compounds and fungi. Most of synthesized compounds displayed good to excellent fungicidal activity against one or multiple plant fungi, some of these compounds showed better activity against one or multiple plant fungi than commercial standard such as azoxystrobin. Further field experiment suggested that compound 8d showed better efficacy against cucumber $S$. fuliginea at than two commercial standards azoxystrobin and trifloxystrobin at the same application rate. Moreover, the compound $\mathbf{8 d}$ showed similar efficacy against $P$. cubensis as that of pyraclostrobin, but significantly better than that of trifloxystrobin. In summary, an excellent fungicide candidate which reached commercially biological levels against some plant pathogen was developed in this study for further development.

\section{Acknowledgements}

This research was in part financial supported by the International Science \& Technology Cooperation Program of China (Grant no. 2014DFR41030), the National Natural Science Foundation of China (No. 21372132 and 31571991), the "111" Project of Ministry of Education of China (Project No. B06005) and Tianjin Natural Science Foundation (No.: 14JCYBJC20400). V. A. Bakulev thanks The Ministry of Education and Science of the Russian Federation (State task 4.1626.2014/K).

\section{Notes and references}

1 B. A. Chalmers, H. Xing, S. Houston, C. Clark, S. Ghassabian, A. Kuo, B. Cao, A. Reitsma, C. E. P. Murray and J. E. Stok, Angew. Chem., Int. Ed., 2016, 55, 3580-3585.

2 Anonymous, Nature, 2010, 466, 531-532.

3 P. Jeschke, Pest Manage. Sci., 2016, 72, 433-455.
4 (a) D. W. Bartlett, J. M. Clough, J. R. Godwin, A. A. Hall, M. Hamer and B. Parr-Dobrzanski, Pest Manage. Sci., 2002, 58, 649-662; (b) P. M. Wood and D. W. Hollomon, Pest Manage. Sci., 2003, 59, 499-511; (c) J. O. Obuya and G. D. Franc, Eur. J. Plant Pathol., 2016, 146, 817-827.

5 (a) H. B. Christensen and K. Granby, Food Addit. Contam., 2001, 18, 866-874; (b) S. Tu, L.-H. Xu, L.-Y. Ye, X. Wang, Y. Sha and Z.-Y. Xiao, J. Agric. Food Chem., 2008, 56, 52475253; (c) Y. Wang, Y.-B. Duan and M.-G. Zhou, Can. J. Plant Pathol., 2014, 36, 354-359; (d) L. Li, M. Li, H. Chi, J. Yang, Z. Li and C. Liu, J. Fluorine Chem., 2016, 185, 173-180.

6 (a) E. Flampouri, S. Mavrikou, A.-C. Mouzaki-Paxinou and S. Kintzios, Biochem. Pharmacol., 2016, 113, 97-109; (b) J. Leiminger, B. Adolf and H. Hausladen, Plant Pathol., 2014, 63, 640-650.

7 U. Gisi, H. Sierotzki, A. Cook and A. McCaffery, Pest Manage. Sci., 2002, 58, 859-867.

8 (a) Y. J. Zhu, X. F. Guo, Z. J. Fan, L. Chen, L. Y. Ma, H. X. Wang, Y. Wei, X. M. Xu, J. P. Lin and V. A. Bakulev, RSC Adv., 2016, 6, 112704-112711; (b) S. Pulya, Y. Kommagalla, D. G. Sant, S. U. Jorwekar, S. G. Tupe, M. V. Deshpande and C. V. Ramana, RSC Adv., 2016, 6, 11691-11701; (c) B. Varun, G. Divya, A. Vikrant, D. Saurabh and S. Poonam, RSC Adv., 2015, 5, 15233-15266; (d) N. P. Belskaya, V. A. Bakulev and Z. J. Fan, Chem. Heterocycl. Compd., 2016, 52, 627-636; (e) Z. Jin, Nat. Prod. Rep., 2006, 23, 464-496.

9 (a) F. Clerici, M. L. Gelmi, S. Pellegrino and D. Pocar, Top. Heterocycl. Chem., 2007, 9, 179-264; (b) R. V. Kaberdin and V. I. Potkin, Russ. Chem. Rev., 2002, 71, 673-694; (c) X. Y. Chen, L. Y. Dai, Y. D. Li, W. T. Mao, Z. Fang, J. J. Li, D. Wang, K. Tatiana and Z. J. Fan, Chin. J. Pestic. Sci., 2013, 15, 140-144.

10 (a) Y. Bektas and T. Eulgem, Front. Plant Sci., 2015, 5, 804; (b) X. Y. Chen, D. Wang, J. Huang, Y. Huang and Z. J. Fan, J. China Agrochem., 2012, 56, 31-34.

11 D. K. Friel, M. L. Snapper and A. H. Hoveyda, J. Am. Chem. Soc., 2008, 130, 9942-9951.

12 F. Al-Saffar, S. Berlin, T. Musil and S. Sivadasan, WO Pat., 2006/090153, 2006.

13 P. Strazzolini and A. Pavsler, Ind. Eng. Chem. Res., 2005, 44, 1625-1626.

14 Z. J. Fan, Z. K. Yang, H. K. Zhang, N. Mi, H. Wang, F. Cai, X. Zuo, Q. X. Zheng and H. B. Song, J. Agric. Food Chem., 2010, 58, 2630-2636.

15 Y. Q. Xie, Y. B. Huang, J. S. Liu, L. Y. Ye, L. M. Che, S. Tu and C. L. Liu, Pest Manage. Sci., 2015, 71, 404-414. 